\title{
Development and validation of a simple spectrophotometric method for the determination of methyldopa in both bulk and marketed dosage formulations
}

\author{
Paulo Roberto da Silva Ribeiro*, Reginária Morais Duarte
}

Centre for Social Science, Health and Technology, Federal University of Maranhão, Imperatriz, MA, Brazil

\begin{abstract}
A simple, precise, sensitive, rapid, specific and economical spectrophotometric method was developed to determine methyldopa (MTD) content in bulk and pharmaceutical dosage formulations. The proposed method was based on the formation of a colored product from the nitrosation reaction of MTD with sodium nitrite in an acid medium. The resultant nitroso derivative species reacts further with sodium hydroxide and is converted it into a more stable compound. This yellow nitrosation product exhibited an absorption maximum at $430 \mathrm{~nm}$. Beer's Law was obeyed in a concentration range of 6.37 to $82.81 \mu \mathrm{g}$ $\mathrm{mL}^{-1}$ MTD with an excellent coefficient of determination $\left(R^{2}=0.9998\right)$. No interference was observed from common excipients in formulations. The results showed the method to be simple, accurate and readily applied for the determination of MTD in pure form and in pharmaceutical preparations. The analytical results obtained for these products using the proposed method are in agreement with those of the Brazilian Pharmacopoeia procedure at a 95\% confidence level.
\end{abstract}

Uniterms: Methyldopa/spectrophotometric determination. Pharmaceutical formulations/quality control. Spectrophotometry/qualitative analysis.

Desenvolveu-se método espectrofotométrico simples, preciso, sensível, rápido, específico e econômico para a determinação do teor de metildopa (MTD) em matéria-prima e em formulações farmacêuticas. O método proposto baseia-se na formação de um produto colorido resultante da reação de nitrosação da MTD com nitrito de sódio em meio ácido. A espécie resultante (nitroso derivado) reage com hidróxido de sódio e é convertida a um composto mais estável de cor amarela. Este produto exibiu máximo de absorção a $430 \mathrm{~nm}$. A lei de Beer foi obedecida na faixa de concentração de 6,37 a 82,81 $\mu \mathrm{g} \mathrm{mL}^{-1}$ de MTD com excelente coeficiente de determinação $\left(R^{2}=0,9998\right)$. Não se observou interferência de excipientes comumente encontrados em formulações farmacêuticas comerciais. Os resultados demonstraram que o método proposto apresenta simplicidade, excelentes precisão e exatidão e pode ser aplicado para a determinação de MTD na sua forma pura e em preparações farmacêuticas. Os resultados analíticos obtidos pelo método proposto estão de acordo com aqueles obtidos pelo método oficial descrito na Farmacopéia Brasileira, a um nível de confiança de $95 \%$.

Unitermos: Metildopa/determinação espectrofotométrica. Formulações farmacêuticas/controle de qualidade. Espectrofotometria/análise qualitativa.

\section{INTRODUCTION}

Methyldopa (MTD), chemically known as $\alpha$-methyl-3,4-dihydroxyphenylalanine (Figure 1), is a catechol derivative (catecholamine) widely used as an antihypertensive agent. MTD is a centrally acting alpha ${ }_{2}-$

\footnotetext{
*Correspondence: P. R. S. Ribeiro. Centre for Social Science, Health and Technology, Universidade Federal de Maranhão. Rua Urbano Santos, s/n Centro, 65900-000 - Imperatriz - MA, Brasil. E-mail: pauloufma@ufma.br
}

adrenoreceptor agonist, which reduces sympathetic tone and produces a fall in blood pressure (Hoffman, 2005).

Several types of analytical procedures have been<smiles>C[C@@](N)(Cc1ccc(O)c(O)c1)C(=O)O</smiles>

FIGURE 1 - Chemical structure of methyldopa. 
employed for the analysis of catechol derivatives in pharmaceutical formulations and/or biological specimens. These procedures include: titrimetric determination (Walash, Abououf, Salem, 1982; Mohamed, Salem, 1984; Amin, 1986; Salem, 1987; Salem, 1993a; Farmacopeia Brasileira, 2010; USP, 2013), gas chromatography (Lee, Hong-You, Fowlie, 1989; Sharma et al., 1996), kinetic methods (Martinez-Lozano et al., 1991), fluorimetry (Salem, 1993b), chemiluminescence (Nozaki et al., 1996; Nozaki et al., 1999), amperometry (Garrido, Lima, Delerue-Mattos, 1997), high-performance liquid chromatography (Tsuchiya et al., 1997; Parsons, Kerr, Weiss, 1998), voltammetric determination (Kozminski et al., 1998) and diffuse reflectance spectroscopy (Ribeiro, Pezza, Pezza, 2006). Some of these methods are complex for routine analysis and either require expensive or sophisticated instruments or involve procedures entailing rigorous control of the experimental conditions. Most of the titrimetric methods reported were indirect titrations and based on reduction reactions, which suffer interferences from unsaturated organic compounds. The official method reported in the Brazilian Pharmacopoeia (Farmacopeia brasileira, 2010) and in USP (2013) describes a nonaqueous titration for the assay of MTD.

Spectrophotometric methods have been proposed for the determination of catecholamines, such as MTD. A differential UV spectrophotometric procedure has also been used for the determination of MTD in pharmaceutical formulations in the presence of germanium dioxide at $292 \mathrm{~nm}$ (Davidson, 1984). MTD has been determined in the visible region after reaction with 2,3,5-triphenyltetrazolium chloride (El-Rabbat, Omar, 1978), potassium bromate (Mohamed, Salem, 1984), vanillin (Salem, 1985), $p$-dimethylaminocinnamaldehyde (Walash, Abououf, Salem, 1985), molybdophosphoric acid in sulphuric acid medium (Issopoulos, 1989), $\mathrm{Fe}(\mathrm{III}), o$-phenanthroline (Issopoulos, 1990), ferric chloride (Zivanovic, Vasiljevic, Radulovic, 1991), neotetrazolium chloride (Issopoulos, Economou, 1993), metaperiodate (Nevado, Gallego, Laguna, 1995), barbituric acid (Aman et al., 1998), isoniazid in the presence of $N$-bromosuccinimide (Nagaraja et al., 1998), polyphenol oxidase enzyme (Vieira, Fatibello Filho, 1998), diazotized sulfanilamide in the presence of molybdate (Nagaraja, Vasantha, Sunitha, 2001a), semicarbazide hydrochloride in the presence of potassium persulfate (Nagaraja et al., 2001b), ammonium molybdate (Ribeiro et al., 2005a; Ribeiro, Pezza, Pezza, 2005b), 2,2-diphenyl-picrylhydrazyl (Matos, Silva, Ribeiro, 2012) and ferric chloride/nitroso-R-salt (Al Abachi, Hadi, 2013). However, most of these methods suffer from several disadvantages, such as long-waiting times or a heating step for reaction development, instability of the colored species, complex procedure, requirement for nonaqueous media, poor detection limit, or lack of previous application to pharmaceutical formulations.

The present study reports a simple, precise, sensitive, rapid, specific and economical spectrophotometric method developed to determine the (MTD) content in bulk and pharmaceutical dosage formulations. The proposed method was based on the formation of a nitrous derivative of MTD. The yellow-colored product had maximum absorption at $430 \mathrm{~nm}$. The proposed method has none of the disadvantages of interference from the excipients normally found with MTD in tablet dosage formulations and involves no extraction or heating steps. The method was used to determine MTD in pharmaceutical formulations. The results obtained by applying the proposed method showed relatively good agreement with those obtained using the standard procedure reported in the Brazilian Pharmacopoeia (Farmacapeia Brasileira, 2010) at a 95\% confidence level.

\section{MATERIAL AND METHODS}

\section{Apparatus}

A Femto Model CIRRUS 80ST spectrophotometer with $1 \mathrm{~cm}$ matched silica cells was used for all absorbance measurements. Volume measurements were made with a plunger-operated pipetter $(100-1000 \mu \mathrm{L})$ and Metrohm model 665 automatic burettes. All experiments were performed in a thermostatically-controlled room $(25 \pm 1)^{\circ} \mathrm{C}$. A Hanna Model Pack pH 21 digital pH-meter, calibrated with standard buffer solutions, was used for $\mathrm{pH}$ measurements.

\section{Chemicals and reagents}

All of the reagents used were of analytical reagent grade. Deionized water was used throughout the experiments.

A stock solution $\left(\mathrm{MTD}_{\mathrm{S}}-318.4 \mu \mathrm{g} \mathrm{ml}^{-1}\right)$ of MTD standard (Pharma Nostra - São Paulo, Brazil, purity grade $>99.2 \%$ ) was prepared daily by dissolving $15.9 \mathrm{mg}$ of the reference substance in water and diluting to the mark in a $50 \mathrm{ml}$ volumetric flask. Working standard solutions were obtained by appropriate dilution of this stock solution with the same solvent and were standardized using the standard procedure reported in the Brazilian Pharmacopoeia (Farmacopeia Brasileira, 2010).

Aqueous solutions of sodium nitrite $\left[0.6 \mathrm{~mol} \mathrm{~L}^{-1}\right]$ 
(Merck), sodium hydroxide $\left[5.0 \times 10^{-2} \mathrm{~mol} \mathrm{~L}^{-1}\right]$ (Merck), and hydrochloric acid $\left[1.6 \times 10^{-2} \mathrm{~mol} \mathrm{~L}^{-1}\right]$ (Merck) were prepared and used.

Pharmaceutical formulations (tablets) of four commercial brands were analyzed. These tablets were purchased from local drugstores and all were tested prior to their respective listed expiry dates. All pharmaceuticals studied were package labeled to contain 250 or $500 \mathrm{mg}$ of MTD per tablet.

The excipients used in the interference study were of pharmaceutical grade. Thus, sucrose, glucose, talc, fructose, lactose, polyethylene glycol, microcrystalline cellulose, croscarmellose sodium, starch, polyvinylpyrrolidone and magnesium stearate were purchased from Sigma (St. Louis, MO, p. a.).

\section{Methodology}

\section{Determination of wavelength of maximum absorption}

A reference substance stock solution $\left(\mathrm{MTD}_{\mathrm{S}}\right)$ (50.94 $\mu \mathrm{g} \mathrm{mL}^{-1}$ of MTD) was transferred into a $5 \mathrm{~mL}$ calibrated flask. In this flask, $1.0 \mathrm{~mL}$ of hydrochloric acid $\left(1.6 \times 10^{-2} \mathrm{~mol} \mathrm{~L}^{-1}\right)$ and $1.0 \mathrm{~mL}$ of sodium nitrite $\left(0.6 \mathrm{~mol} \mathrm{~L}^{-1}\right)$ were added and kept aside for $5 \mathrm{~min}$; then $1.0 \mathrm{~mL}$ of sodium hydroxide $\left(5.0 \times 10^{-2} \mathrm{~mol} \mathrm{~L}^{-1}\right)$ was added to the solution. After five minutes, the volume was then made up with deionized water. A spectroscopic scan (400-800 $\mathrm{nm})$ was carried out with this solution to determine the $\lambda_{\max }$ for the detection of MTD, against the corresponding reagent blank.

\section{Linearity and range}

Aliquots of reference substance stock solution ranging from 6.37 to $82.81 \mu \mathrm{g} \mathrm{mL}^{-1}$ MTD were transferred to a series of $5.0 \mathrm{~mL}$ volumetric flasks. To each flask, $1.0 \mathrm{~mL}$ of hydrochloric acid $\left(1.6 \times 10^{-2} \mathrm{~mol} \mathrm{~L}^{-1}\right)$ and $1.0 \mathrm{~mL}$ of sodium nitrite $\left(0.6 \mathrm{~mol} \mathrm{~L}^{-1}\right)$ were added and kept aside for $5 \mathrm{~min}$; then $1.0 \mathrm{~mL}$ of sodium hydroxide $\left(5.0 \times 10^{-2} \mathrm{~mol} \mathrm{~L}^{-1}\right)$ was added to the solution. After five minutes, the volume was then made up with deionized water. The absorbance was measured at $430 \mathrm{~nm}$ against the corresponding reagent blank. Calibration graphs were prepared by plotting absorbance against drug concentration. These graphs or the corresponding linear least squares equations were used to convert absorbance into MTD concentration, for any given analyzed sample.

\section{Stoichiometric relationship}

Job's method (Foster, 1969) was applied by placing 0.50 to $2.25 \mathrm{~mL}$ of $318.4 \mu \mathrm{g} \mathrm{mL}^{-1}$ MTD solution into a series of $10.0 \mathrm{~mL}$ volume flasks; this was followed by placing 2.25 to $0.50 \mathrm{~mL}$ of $1.5 \times 10^{-3} \mathrm{~mol} \mathrm{~L}^{-1}$ sodium nitrite, and $1.0 \mathrm{~mL}$ of hydrochloric acid $\left(1.6 \times 10^{-2} \mathrm{~mol} \mathrm{~L}^{-1}\right)$ into the flasks which were kept aside for $5 \mathrm{~min}$; then $1.0 \mathrm{~mL}$ of sodium hydroxide $\left(5.0 \times 10^{-2} \mathrm{~mol} \mathrm{~L}^{-1}\right)$ was added to the solution. After five minutes, the volume was then made up with deionized water. The absorbance was measured at $430 \mathrm{~nm}$ against the corresponding reagent blank. The results were plotted as shown in Figure 5, indicating the existence of 1:1 (MTD: sodium nitrite).

\section{Stability study}

The stability of the product formed under the abovementioned optimum conditions was investigated. For this study, a reference substance stock solution $\left(50.94 \mu \mathrm{g} \mathrm{mL}^{-1}\right.$ of MTD) was transferred into a $5 \mathrm{~mL}$ calibrated flask and analyzed according to the recommended procedure for the calibration curve. This solution was kept for $24 \mathrm{~h}$ at room temperature and subsequently analyzed to test for short-term stability.

\section{Intra-day precision (repeatability) and inter-day} precision (intermediate precision) studies

MTD tablets were finely powdered and a sample stock solution $\left(\mathrm{MTD}_{\mathrm{P}}\right)$ of $318.4 \mu \mathrm{g} \mathrm{mL}^{-1}$ was prepared following the same dilution pattern of $\mathrm{MTD}_{\mathrm{S}}$. Three different aliquots of $\mathrm{MTD}_{\mathrm{P}}$ were then diluted to obtain the concentrations of $31.84,44.58$ and $57.31 \mu \mathrm{g} \mathrm{mL}^{-1}$ and analyzed according to the recommended procedure for the calibration curve. The quantity per tablet was calculated from the standard calibration graph. This procedure was repeated on the two proceeding days.

\section{Specificity in the presence of excipients}

To assess the usefulness of the proposed method, the effect of the common components (additives, adjuvants and excipients) which often accompany MTD in tablet dosage formulations (silicon dioxide, sodium laureth sulfate, mannitol, sodium metabisulfite, polyethylene glycol, citric acid, lactose, microcrystalline cellulose, croscarmellose sodium, talc, starch and magnesium stearate) were investigated using the developed method. The ratios of the concentrations of MTD $\left(44.58 \mu \mathrm{g} \mathrm{mL}^{-1}\right)$ to the excipient substances were fixed at 1.0 and 10.0.

\section{Procedure for the assay of MTD in pharmaceutical samples}

Four market brands of MTD tablets purchased from local drugstores were randomly selected and analyzed using the newly developed and validated method. For the determination of MTD in pharmaceutical samples, the average tablet weight was calculated from the 


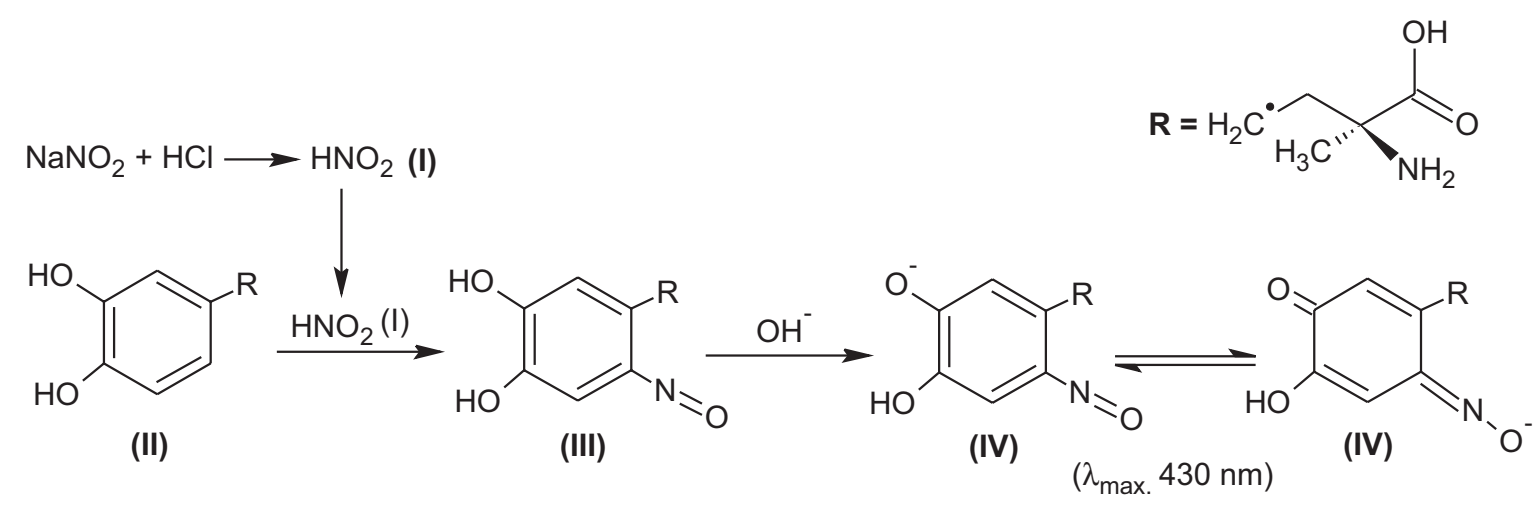

FIGURE 2 - Suggested mechanism of nitration reaction of MTD.

contents of 20 tablets that were finely powdered and weighed. A portion of this powder, equivalent to ca. $15.8 \mathrm{mg}$ of MTD was accurately weighed and dissolved in $25 \mathrm{ml}$ of deionized water by shaking for $15 \mathrm{~min}$ in a mechanical shaker. The resulting mixture was filtered and transferred into $50.0 \mathrm{~mL}$ graduated flasks, and the volume completed with deionized water. Aliquots from this solution, containing the equivalent of $44.58 \mu \mathrm{g} \mathrm{mL}^{-1}$ of MTD, were transferred into $5.0 \mathrm{~mL}$ graduated flasks and analyzed according to the recommended procedure for the calibration curve. The quantity per tablet was calculated from the standard calibration graph.

\section{Accuracy/recovery studies}

To study the accuracy of the proposed method and determine the interference from the excipients used in the dosage forms, recovery experiments were carried out by the standard addition method. This study was performed by addition of known amounts $(17.19 ; 19.10 ; 21.01$ and $22.92 \mu \mathrm{g} \mathrm{mL}^{-1}$, corresponding to levels of $90 ; 100 ; 110$ and $120 \%$, respectively) of the standard substance (pure drug - MTD) to a known concentration of the previously analyzed commercial tablets (samples A, B, C and D). The resulting mixtures were analyzed according to the recommended procedure for the calibration curve. The recovery of drug was calculated by comparing the concentration obtained from the spiked mixtures with those of the pure drug.

\section{RESULTS AND DISCUSSION}

Sodium nitrite and hydrochloric acid react to produce nitrous acid (Figure 2, compound I). Owing to the presence of phenolic hydroxy groups in compounds (such as MTD - Figure 1), the reaction of this acid leads to the formation of nitroso derivatives (yellow-colored products - Figure 2, compound III) which are unstable (Suarez, Vieira, Fatibello Filho, 2005). The products formed in acid media are unstable but can be stabilized by the interaction with an alkaline reagent to form the highly stable compounds (Figure 2, compound IV). This indicates that the alkalinisation of the medium gives rise to the formation of a bathochromic shift, together with a hyperchromic effect (Belal et al., 1979).

The absorption spectrum of the colored product shows maximum absorption at $430 \mathrm{~nm}$ (Figure 3). Thus, the probable mechanism for the reaction between MTD (catecholamine) and the sodium nitrite in an acid medium involves the formation of nitroso derivatives as shown in Figure 2. This type of formation is probably due to the contribution of an extra pair of unshared electrons in the interaction with the aromatic nucleus (Daveu et al., 1997; d'Ischia, Costantini, 1995).

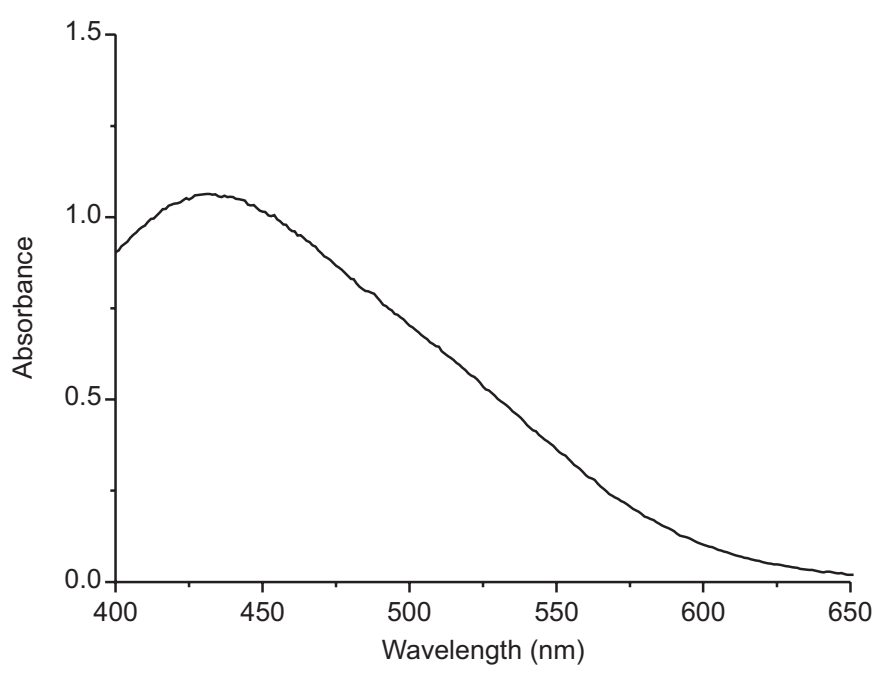

FIGURE 3 - Absorption spectrum of nitroso derivative of MTD in alkaline medium.

\section{Method development and optimization}

The effect of different volumes of the reagent used was investigated to obtain optimum results for the 
determination of MTD. The optimum conditions were established based on the development of maximum color intensity and stability upon variation of parameters affecting the nitrosation reaction of MTD by the sodium nitrite in an acid medium.

Using different volumes of $\mathrm{HCl}$ and of $\mathrm{NaOH}$, it was found that maximum color intensity and stability were obtained by developing the reactions in $1.0 \mathrm{~mL}$ of hydrochloric acid $\left(1.6 \times 10^{-2} \mathrm{~mol} \mathrm{~L}^{-1}\right)$ and $1.0 \mathrm{~mL}$ of sodium hydroxide $\left(5.0 \times 10^{-2} \mathrm{~mol} \mathrm{~L}^{-1}\right)$, as described in the recommended procedure. The adopted concentration of sodium nitrite $\left(0.6 \mathrm{~mol} \mathrm{~L}^{-1}\right)$ was found to be sufficient for providing maximum and repeatable color intensity, but when the concentration of reagent fell below this concentration the absorbance decreased while at higher concentrations the absorbance was not increased.

The order of addition of the reactants recommended in the general procedure produced quantitative results. Any other order was found to produce deviant results and reduced color intensity.

\section{Linearity and range}

The analytical curve (Figure 4) was obtained by the method of least squares from seven points, each of which was the average of three determinations. The proposed analytical method was validated by evaluating linear dynamic range, precision, limit of detection (LOD), and limit of quantitation (LOQ). Under the experimental described, Beer's law was obeyed in the concentration range from 6.37 to $82.81 \mu \mathrm{g} \mathrm{mL}^{-1} \mathrm{MTD}$ with an excellent coefficient of determination $\left(R^{2}=0.9998\right)$. The absorbance values for this concentration range were adjusted by the

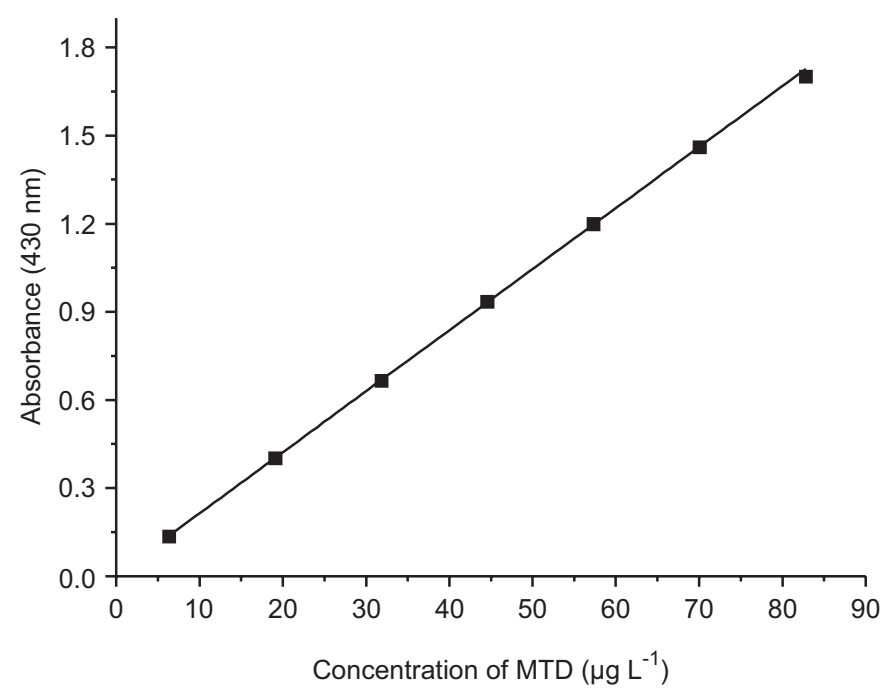

FIGURE 4 - Analytical curve for determination of MTD. equation: $A=5.92 \times 10^{-3}+20.79 \times 10^{-3}{ }^{\circ} \mathrm{C}$, where $\mathrm{C}$ is the concentration of MTD in $\mu \mathrm{g} \mathrm{mL}^{-1}$ (molar absorptivity $(\varepsilon)$ : $\left.4.423 \times 10^{3} \mathrm{~mol}^{-1} \mathrm{~cm}^{-1}\right)$. The LOD $\left(3 . \mathrm{SD}_{\text {blank }} / \mathrm{slope}\right.$ of curve) and LOQ (10.SD $\mathrm{Slank} /$ slope of curve) were $2.52 \times 10^{-2} \mu \mathrm{g} \mathrm{mL}^{-1}$ and $7.68 \times 10^{-2} \mu \mathrm{g} \mathrm{mL}^{-1}$ of MTD, respectively ( $\mathrm{ICH}, 2005)$.

\section{Determination of stoichiometric relationships}

Job's method of continuous variations (Foster, 1969) was employed for the determination of stoichiometric relationships: equimolar concentrations of MTD and sodium nitrite was found to be 1:1 (Figure 5).

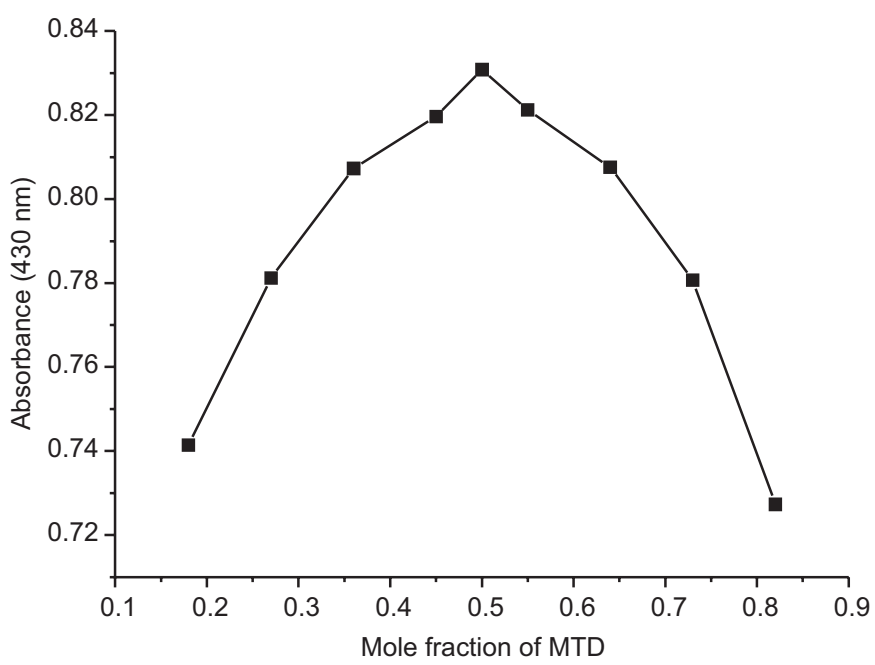

FIGURE 5 - Continuous variation plot for MTD with sodium nitrite.

\section{Intra-day and inter-day precision}

Assay precision was defined by determining intraday and inter-day precision, expressed as relative standard deviation (RSD). The inter-day variation was evaluated over 3 days. The intra-day and inter-day precision studies (Table I) of the developed method confirmed adequate sample stability and method reliability, where all the RSDs were $<2.0 \%$.

\section{Stability}

The stability of the product formed under the abovementioned optimum conditions was investigated. The data given in Table II show that full color development is immediate at room temperature $\left(25^{\circ} \mathrm{C}\right)$ and the values of absorbance of the product formed were found to remain unchanged after standing for 24 hours at room temperature. This product was stable in the temperature 
TABLE I - Intra-day and inter-day precision determined for three different concentrations of MTD $(n=3)$

\begin{tabular}{|c|c|c|c|c|c|c|}
\hline \multirow[b]{2}{*}{$\begin{array}{l}\text { Concentration } \\
\left(\mu \mathrm{g} \mathrm{mL} L^{-1}\right)\end{array}$} & \multicolumn{3}{|c|}{ Intra-day precision } & \multicolumn{3}{|c|}{ Inter-day precision } \\
\hline & $\begin{array}{c}\text { Absorbance } \\
\text { measured } \\
(\text { Mean } \pm \text { SD) } \\
\end{array}$ & $\begin{array}{l}\text { RSD } \\
(\%)\end{array}$ & $\begin{array}{c}\text { Average potency } \\
\text { (\%) }\end{array}$ & $\begin{array}{c}\text { Absorbance } \\
\text { measured } \\
(\text { Mean } \pm \text { SD) } \\
\end{array}$ & $\begin{array}{l}\text { RSD } \\
(\%)\end{array}$ & $\begin{array}{c}\text { Average potency } \\
(\%)\end{array}$ \\
\hline 31.84 & $0.6636 \pm 0.0015$ & 0.2260 & 99.77 & $0.6720 \pm 0.0038$ & 0.5655 & 101.04 \\
\hline 44.58 & $0.9239 \pm 0.0033$ & 0.3572 & 98.92 & $0.9261 \pm 0.0054$ & 0.5831 & 99.15 \\
\hline 57.31 & $1.2084 \pm 0.0099$ & 0.8293 & 100.81 & $1.2101 \pm 0.0087$ & 0.7189 & 100.95 \\
\hline
\end{tabular}

TABLE II - Optical stability of the reaction product at room temperature $\left(25^{\circ} \mathrm{C}\right)^{\mathrm{a}}$

\begin{tabular}{cc}
\hline Time (min) $^{(\operatorname{mobs}}$ & Absonce $^{\mathrm{b}}$ \\
\hline 0 & 1.0630 \\
5 & 1.0624 \\
10 & 1.0622 \\
15 & 1.0622 \\
20 & 1.0635 \\
25 & 1.0643 \\
30 & 1.0633 \\
$35^{\mathrm{c}}$ & 1.0619 \\
\hline
\end{tabular}

${ }^{a}$ MTD concentration: $50.94 \mu \mathrm{g} \mathrm{mL}^{-1}$. ${ }^{\mathrm{b}}$ Measurements taken at $430 \mathrm{~nm}$ against the reagent blank for reactants at room temperature $\left(25^{\circ} \mathrm{C}\right)$, as described in the recommended procedure. ${ }^{\mathrm{c}} \mathrm{Absorbance}$ remains unchanged after standing for 24 hours at $25^{\circ} \mathrm{C}$.

range of $20-60{ }^{\circ} \mathrm{C}$. However, a temperature of $25^{\circ} \mathrm{C}$ was chosen for the absorbance measurements.

\section{Specificity in the presence of excipients}

Since the aim of this study was to determine MTD in pharmaceuticals, the effects of the most commonly used excipients were carefully examined. The excipients studied were silicon dioxide, sodium laureth sulfate, mannitol, sodium metabisulfite, polyethylene glycol, citric acid, lactose, microcrystalline cellulose, croscarmellose sodium, talc, starch and magnesium stearate. For this study, solutions containing MTD and each of the excipients taken separately at concentrations greater than or equal to 10 times that of MTD, were stirred with water in a magnetic mixer for 15 minutes, diluted, filtered when necessary, and analyzed under the same conditions described in the preparation of analytical curve.

The effect of each excipient was considered interference when the absorbance signal showed an error greater than or equal to $3.0 \%$ in the determination of the drug. The percentage of MTD found in these solutions ranged from 99.0 to $100.5 \%$, with coefficient of variation values of less than $2.0 \%$ for three replicates, indicating that no interferences were observed under the studied conditions.

\section{Content of MTD in marketed brands}

The samples were prepared using the developed method. The proposed method was successfully applied for the determination of MTD in four tablet formulations. The results given in Table III compared favorably with the official method (Farmacopeia Brasileira, 2010), at $95 \%$ confidence level, confirming the applicability of the proposed method for the determination of MTD in pharmaceutical dosage forms (tablets).

The results were subjected to a paired comparison test (Miller, Miller, 1993); the data of $t$ and $F$ ratios show no significant differences between the results of the proposed and the official methods, at a $95 \%$ confidence level. The RSD values obtained for the samples ranged from 0.7 to $3.8 \%$, as shown in Table III. According to Horwitz (1982), the maximum RSD value acceptable for the working level of the analyte $\left(48.58 \mu \mathrm{g} \mathrm{mL}^{-1}\right)$ is $8.0 \%$. The AOAC (1993) set the maximum acceptable RSD value at $5.3 \%$ for the same analyte level. Therefore, the spectrophotometric method for determination of MTD in pharmaceutical formulations reported in this paper is precise, accurate, and suitable for use in routine analysis.

\section{Accuracy/recovery and repeatability studies}

In order to investigate the presence of matrix effects and to check the accuracy and precision of the developed method a recovery study was also carried out. The results of the recovery tests are given in Table IV. The mean recovery values for all samples within the $100.0-101.0 \%$ range and RSD within $0.9-1.6 \%$ confirm an accurate and precise method for application to pharmaceutical dosage 
TABLE III - Determination of MTD in commercial pharmaceutical preparations

\begin{tabular}{|c|c|c|c|c|c|c|c|}
\hline \multirow{2}{*}{ Sample } & \multirow{2}{*}{ Label value $^{a}$} & \multicolumn{4}{|c|}{ Proposed method } & \multicolumn{2}{|c|}{ Official method } \\
\hline & & Found $^{\text {b }}$ & $\operatorname{RSD}(\%)^{c}$ & $t$-value $(2.78)^{\mathrm{d}}$ & $F$-value $(19.00)^{\mathrm{d}}$ & Found $^{\mathrm{b}}$ & $\operatorname{RSD}(\%)$ \\
\hline A & 250.0 & $274.2 \pm 10.4$ & 3.8 & 1.87 & 3.00 & $261.2 \pm 6.0$ & 2.3 \\
\hline B & 250.0 & $255.6 \pm 5.2$ & 2.0 & 1.33 & 1.13 & $250.1 \pm 4.9$ & 2.0 \\
\hline $\mathrm{C}$ & 500.0 & $501.0 \pm 4.5$ & 0.9 & 2.65 & 2.99 & $493.0 \pm 2.6$ & 0.5 \\
\hline D & 500.0 & $499.7 \pm 3.5$ & 0.7 & 2.41 & 3.78 & $505.2 \pm 1.8$ & 1.4 \\
\hline
\end{tabular}

${ }^{a}$ Label for content in tablets: $\mathrm{mg}$ unit ${ }^{-1}$. ${ }^{\mathrm{b}}$ Average value \pm standard deviation (SD) of three determinations. ${ }^{\mathrm{c}}$ Relative standard deviation (RSD) of three determinations. ${ }^{\mathrm{d}}$ Figures between parentheses are the theoretical values of $t$ and $F$ at $P=0.05$.

TABLE IV - Recovery/accuracy data of the proposed method for the pharmaceutical formulations spiked with four different concentrations of MTD

\begin{tabular}{|c|c|c|c|}
\hline Sample & Added $\left(\mu \mathrm{g} \mathrm{mL}^{-1}\right)$ & Found $\left(\mu \mathrm{g} \mathrm{mL} L^{-1}\right)$ & Recovery $(\%)^{\mathrm{a}}$ \\
\hline $\mathrm{A}$ & $\begin{array}{l}17.19 \\
19.10 \\
21.01 \\
22.92\end{array}$ & $\begin{array}{l}17.51 \\
19.04 \\
21.20 \\
23.22\end{array}$ & $\begin{array}{c}101.9 \\
99.7 \\
100.9 \\
101.3 \\
\mu^{\mathrm{a}=} 101.0 \pm 0.9\end{array}$ \\
\hline B & $\begin{array}{l}17.19 \\
19.10 \\
21.01 \\
22.92\end{array}$ & $\begin{array}{l}17.10 \\
19.46 \\
21.18 \\
22.85\end{array}$ & $\begin{array}{c}99.5 \\
101.9 \\
100.8 \\
99.7 \\
\mu^{\mathrm{a}=}=100.5 \pm 1.1 \\
\end{array}$ \\
\hline $\mathrm{C}$ & $\begin{array}{l}17.19 \\
19.10 \\
21.01 \\
22.92\end{array}$ & $\begin{array}{l}17.53 \\
19.27 \\
21.37 \\
22.76\end{array}$ & $\begin{array}{c}102.0 \\
100.9 \\
101.7 \\
99.3 \\
\mu^{\mathrm{a}=}=100.9 \pm 1.2 \\
\end{array}$ \\
\hline $\mathrm{D}$ & $\begin{array}{l}17.19 \\
19.10 \\
21.01 \\
22.92\end{array}$ & $\begin{array}{l}17.07 \\
19.33 \\
20.61 \\
23.26\end{array}$ & $\begin{array}{c}99.3 \\
101.2 \\
98.1 \\
101.5 \\
\mu^{\mathrm{a}=} 100.0 \pm 1.6\end{array}$ \\
\hline
\end{tabular}

${ }^{a}$ Average \pm relative standard deviation (RSD) of three determinations.

forms. Thus, the results indicate no interference from any of the excipients present in tablets.

In the repeatability study, the RSD was $2.0 ; 1.1$; 1.4 and $0.9 \%$ for solution (samples A, B, C and D, respectively) containing an equivalent of $44.58 \mu \mathrm{g} \mathrm{mL}^{-1}$ of MTD $(n=10)$. These results reveal good precision of the proposed method.

\section{CONCLUSION}

The proposed method represents a very simple, cheap, rapid, precise, accurate, highly sensitive and environmentally-friendly (low consumption of reagents/ solvents) analytical method for determining MTD in commercial pharmaceutical preparations with satisfactory recovery. Additionally, the approach fulfils all the main requirements of routine analysis as it is robust, has a low instrumentation and operational cost in comparison to chromatographic methods, and involves no pre-treatment of the sample.

When applied to the assay of various tablet dosage forms, it offers the advantage of not requiring removal of usual excipients since these did not interfere with the determination of MTD. Therefore, the method can be useful in routine quality control analysis of MTD. 


\section{ACKNOWLEDGEMENTS}

We would like to thank the FAPEMA, CNPq and INCUBEM/PROEX/UFMA Foundations (Brazil) for financial support.

\section{REFERENCES}

AL ABACHI, M.Q.; HADI, H. New, simple and validated kinetics spectrophotometric method for determination of methyldopa in its pharmaceutical formulations. Int. $J$. Recent Sci. Res., v.4, n.4, p.320-324, 2013.

AMAN, T.; KHAN, I.U.; ASLAM, N.; AHMED, I. Spectrophotometric determination of methyldopa in pure and pharmaceutical preparations. Anal. Lett., v.31, n.6, p.1007-1020, 1998.

AMIN, D. Titrimetric determination of catecholamines and related-compounds via bromine oxidation and substitution. Analyst, v.111, n.2, p.255-257, 1986.

ASSOCIATION OF OFFICIAL ANALYTICAL CHEMISTS. AOAC. Peer verified methods program: manual on policies and procedures. Arlington: AOAC International, $1993.17 \mathrm{p}$.

BELAL, S.F.; EL SAYED, M.A.H.; EL WALILY, A.; ABDINE, H. Spectrophotometric determination of acetaminophen and salicylamide through nitrosation and subsequent chelation. Analyst, v.104, n.1, p.919-927, 1979.

FARMACOPEIA Brasileira. 5.ed. v.2. Brasília: ANVISA, 2010. p.1143-1145.

DAVEU, C.; SERVY, C.; DENDANE, M.; MARIN, P.; DUCROCQ, C. Oxidation and nitration of catecholamines by nitrogen oxides derived from nitric oxide. Nitric OxideBiol. Chem., v.1, n.3, p.234-243, 1997.

DAVIDSON, A.G. Difference spectrophotometric assay of 1,2-diphenolic drugs in pharmaceutical formulations. 2 . Germanium dioxide reagent. J. Pharm. Sci., v.73, n.11, p.1582-1584, 1984.

D'ISCHIA, M.; COSTANTINI, C. Nitric oxide-induced nitration of catecholamine neurotransmitters: a key to neuronal degeneration? Bioorg. Med. Chem., v.3, n.7, p.923-927, 1995.
EL-RABBAT, N.A.; OMAR, N.M. Colorimetric determination of catecholamines by 2,3,5-triphenyltetrazolium chloride. J. Pharm. Sci., v.67, n.6, p.779-781, 1978.

FOSTER, R. Organic charge transfer complexes. London: Academic Press, 1969. 136 p.

GARRIDO, M.E.; LIMA, J.L.F.C.; DELERUE-MATTOS, C. Flow injection amperometric determination of L-dopa, epinephrine or dopamine in pharmaceutical preparations. $J$. Pharm. Biomed. Anal., v.15, n.6, p.845-849, 1997.

HOFFMAN, B.B. Catecholamines, sympathomimetic drugs, and adrenergic receptor antagonists. In: HARDMAN, J.G.; LIMBIRD, L.E.; MOLINOFF, P.B.; RUDDON, R.W.; GILMAN, A.G. (Eds.). Goodman \& Gilman's the pharmacological basis of therapeutics. 10.ed. New York: Mac Graw-Hill, 2005. chap.10, p.163-165.

HORWITZ, W. Evaluation of analytical methods used for regulation of foods and drugs. Anal. Chem., v.54, n.1, p.67A-76A, 1982.

\section{INTERNATIONAL CONFERENCE ON HARMONIZATION.} ICH Q2 (R1): validation of analytical procedures-text and methodology. Geneva: ICH, 2005. 15 p.

ISSOPOULOS, P.B. Spectrophotometric determination of microquantities of carbidopa, levodopa and $\alpha$-methyldopa using molybdophosphoric acid. Pharm. Acta Helv., v.64, n.3, p.82-85, 1989 .

ISSOPOULOS, P.B. High-sensitivity spectrophotometric determination of trace amounts of levodopa, carbidopa and

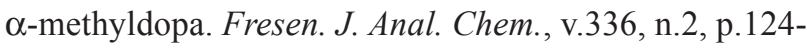
$128,1990$.

ISSOPOULOS, P.B.; ECONOMOU, P.T. A new high-sensitivity spectrophotometric method for the determination of microconcentrations of $\alpha$-methyldopa. Farmaco, v.48, n.1, p.127-135, 1993.

KOZMINSKI, K.D.; GUTMAN, D.A.; DAVILA, V.; SULZER, D.; EWING, A.G. Voltammetric and pharmacological characterization of dopamine release from single exocytotic events at rat pheochromocytoma (PC12) cells. Anal. Chem., v.70, n.15, p.3123-3130, 1998. 
LEE, H.B.; HONG-YOU, R.L.; FOWLIE, P.J.A. Chemical derivatization analysis of phenols: determination of chlorinated phenolics in pulp and paper effluents. J. Assoc. Off. Anal. Chem., v.72, n.6, p.979-984, 1989.

MARTINEZ-LOZANO, C.; PÉREZ-RUIZ, T.; TOMAS, V.; VAL, O. Determination of epinephrine, norepinephrine, dopamine and L-dopa in pharmaceuticals by a photokinetic method. Analyst, v.116, n.8, p.857-859, 1991.

MATOS, O.R.; SILVA, F.C.; RIBEIRO, P.R.S. A new, simple and sensitive analytical method for determination of methyldopa in pharmaceutical formulations using the 2,2-diphenyil-picrylhydrazyl. Lat. Am. J. Pharm., v.31, n.2, p.190-194, 2012.

MILLER, J.C.; MILLER, J.N. Estadística para química analítica, 2.ed. Delaware: Addison-Wesley Iberoamericana, 1993. 209 p.

MOHAMED, W.I.; SALEM, F.B. Spectrophotometric and titrimetric determination of certain adrenergic drugs. Anal. Lett., v.17, n.3, p.191-203, 1984.

NAGARAJA, P.; MURTHY, K.C.S.; RANGAPPA, K.S.; GOWDA, N.M.M. Spectrophotometric methods for the determination of certain catecholamine derivatives in pharmaceutical preparations. Talanta, v.46, n.1, p.39-44, 1998.

NAGARAJA, P.; VASANTHA, R.A.; SUNITHA, K.R. A sensitive and selective spectrophotometric estimation of catechol derivatives in pharmaceutical preparations. Talanta, v.55, n.6, p.1039-1046, 2001a.

NAGARAJA, P.; VASANTHA, R.A.; MURTHY, K.C.S.; RANGAPPA, K.S. Spectrophotometric determination of some aromatic vic-diols in the pharmaceutical formulations. Chem. Anal. (Warsaw), v.46, n.4, p.569-577, 2001 b.

NEVADO, J.J.B.; GALLEGO, J.M.L.; LAGUNA, P.B. Spectrophotometric determination of dopamine and methyldopa with metaperiodate by flow injection analysis. Fresen. J. Anal. Chem., v.353, n.2, p.221-223, 1995.

NOZAKI, O.; IWAEDA, T.; KATO, Y. Amines for detection of dopamine by generation of hydrogen peroxide and peroxyoxalate chemiluminescence. J. Biolumin. Chemilumin., v.11, n.6, p.309-314, 1996.
NOZAKI, O.; IWAEDA, T.; MORIYAMA, H.; KATO, Y. Chemiluminescent detection of catecholamines by generation of hydrogen peroxide with imidazole. Luminescence, v.14, n.3, p.123-127, 1999.

PARSONS, L.R.; KERR, T.M.; WEISS, F. Simple microbore high-performance liquid chromatographic method for the determination of dopamine and cocaine from a single in vivo brain microdialysis sample. J. Chromatogr. B, v.709, n.1, p.35-39, 1998.

RIBEIRO, P.R.S.; GOMES NETO, J.A.; PEZZA, L.; PEZZA, H.R. Flow-injection spectrophotometric determination of methyldopa in pharmaceutical formulations. Talanta, v.67, n.1, p.240-244, 2005a.

RIBEIRO, P.R.S.; PEZZA, L.; PEZZA, H.R. Spectrophotometric determination of methyldopa in pharmaceutical formulations. Eclét. Quím., v.30, n.3, p.23-28, 2005 b.

RIBEIRO, P.R.S.; PEZZA, L.; PEZZA, H.R. Determination of methyldopa in pharmaceutical formulations by combined spot test-diffuse reflectance spectroscopy. J. Braz. Chem. Soc., v.17, n.4, p.674-679, 2006.

SALEM, F.B. Colorimetric determination of certain sympathomimetic amines. Anal. Lett., v.18, n.9, p.10631075, 1985.

SALEM, F.B. Spectrophotometric and titrimetric determination of catecholamines. Talanta, v.34, n.9, p.810-812, 1987.

SALEM, F.B. Titrimetric and spectrophotometric determination of catecholamines. Anal. Lett., v.26, n.9, p.1959-1966, 1993a.

SALEM, F.B. Spectrophotometric and fluorometric determination of catecholamines. Anal. Lett., v.26, n.2, p.281-294, 1993 b.

SHARMA, C.; MOHANTY, S.; KUMAR, S.; RAO, N.J. Gas chromatographic analysis of chlorophenolic, resin and fatty acids in chlorination and caustic extraction stage effluent from kahi-grass. Analyst, v.121, n.12, p.1963-1967, 1996.

SUAREZ, W.T.; VIEIRA, H.J.; FATIBELLO FILHO, O. Determinação de paracetamol em produtos farmacêuticos empregando um sistema de análise por injeção em fluxo com geração de ácido nitroso. Eclét. Quím., v.30, n.1, p.23-28, 2005. 
TSUCHIYA, M.; SATO, M.; KATO, H.; OKUBO, T.; JUNEJA, L.R.; KIM, M. Simultaneous determination of catechins in human saliva by high-performance liquid chromatography. J. Chromatogr. B, v.703, n.1-2, p.253-258, 1997.

UNITED STATES PHARMACOPEIA. 36.ed. Rockville: United States Pharmacopeial Convention, 2013. v.3, p.2889-2890.

VIEIRA, I.C.; FATIBELLO FILHO, O. Spectrophotometric determination of methyldopa and dopamine in pharmaceutical formulations using a crude extract of sweet potato root (Ipomoea batatas (L.) lam.) as enzymatic source. Talanta, v.46, n.4, p.559-564, 1998.
WALASH, M.I.; ABOUOUF, A.; SALEM, F.B. Spectrophotometric and titrimetric determination of certain adrenergic drugs, using organic brominating agents. J. Assoc. Off. Anal. Chem., v.65, n.6, p.1445-1451, 1982.

WALASH, M.I.; ABOUOUF, A.; SALEM, F.B. Colorimetric determination of sympathomimetic amines methyldopa and noradrenaline. J. Assoc. Off. Anal. Chem., v.68, n.1, p.91-95, 1985.

ZIVANOVIC, L.; VASILJEVIC, S.; RADULOVIC, D. Colorimetric assay of methyldopa bulk drug and tablets as Fe(III) complex. Boll. Chim. Farm., v.130, n.5, p.162-165, 1991.

Received for publication on $24^{\text {th }}$ July 2013 Accepted for publication on $04^{\text {th }}$ October 2013 